\title{
Pharmacokinetics and Distribution of Florfenicol in Bronchial Secretions of Healthy and Pasteurella multocida Infected Calves
}

\section{A. Ramadan and A. M. Abd El-Aty*}

Department of Pharmacology, Faculty of Veterinary Medicine, Cairo University, Giza-12211, Egypt

\begin{abstract}
Florfenicol was administered intravenously and intramuscularly at a dose rate of $20 \mathrm{mg} / \mathrm{kg}$ bwt to determine its concentration in blood and bronchial secretions as well as kinetic behavior in healthy and diseased calves. Sever acute bronchopneumonia was induced via inoculating the animals with Pasteurella multocida. Following intravenous (i.v) administration, the serum concentration - time curve indicated a two compartment open model with a mean elimination half-lives $\left(\mathrm{t}_{1 / 2 \beta}\right)$ of 4.10 and $4.84 \mathrm{~h}$ in healthy and infected calves, respectively. The mean volumes of distribution at steady state (Vdss) were 0.68 and $0.63 \mathrm{~L} / \mathrm{kg}$ and the total body clearances $\left(\mathrm{C}_{\text {ltot }}\right)$ were 0.15 and $0.11 \mathrm{~L} / \mathrm{kg} / \mathrm{h}$ with mean residence time (MRT) of 0.05 and $0.05 \mathrm{~h}$, respectively. Florfenicol was slowly eliminated from serum and bronchial secretions with elimination half-lives ( $\left.t_{1 / 2 e l}\right)$ of (12.43 and $17.23 \mathrm{~h}$ ) and (13.74 and 22.46 h), respectively, following intramuscular (i.m.) injection. The peak concentrations (Cmax) in serum and bronchial secretions were $(3.70$ and $4.06 \mu \mathrm{g} / \mathrm{ml})$ and $(6.88$ and $7.62 \mu \mathrm{g} / \mathrm{ml})$ attained at $(3.07$ and $3.01 \mathrm{~h})$ and $(1.54$ and 1.70 h), respectively. The drug is extensively distributed to bronchial secretions with $A U C_{\text {bronchial secretion }} / A C_{\text {serum }}$ ratio of 1 : 2.53 and 1: 2.03, respectively. The clinical and hematological parameters in calves treated intramuscularly returned to normal faster than those treated intravenously. These results suggest that i.m. injection of florfenicol could be used for treatment of acute $P$. multocida bronchopneumonia in calves.
\end{abstract}

Keywords: Florfenicol; Disposition kinetics; Calves; Healthy; Diseased, Bronchial secretion

\section{Introduction}

Bronchopneumonia is one of the most economically important respiratory disorders affecting calves reared indoors [1,2]. The etiology of calf bronchopneumonia is complicated and could involve viruses, Mycoplasmas, and bacteria [3]. Bacteria, particularly Pasteurella species, play an important role in many outbreaks of calf bronchopneumonia. All Pasteurella species occur as commensals in the upper respiratory and alimentary tracts of their various hosts. In turn, they might increase the severity of the primary lung damage caused by viruses and exacerbate the clinical signs, frequently with fatal outcome (i.e. secondary to other infections). Varieties of some species, including P. multocida and / or P. haemolytica could act as primary pathogens and would produce sever acute pneumonia in calves [4-7].

Florfenicol is a broad spectrum antibiotic structurally related to thiamphenicol, which differ in substitution of a fluorine atom for a hydroxyl group. Because of this substitution, the antibacterial spectrum activity of florfenicol is superior to that of thiamphenicol $[8,9]$. It is active against many chloramphenicol-resistant strains of organisms, including Pasteurella multocida, Pasteurella haemolytica, Klebsiella pneumoniae, Enterobacter cloacae, Shigella dysenteriae, Salmonella typhi, Escherichia coli, and Haemophilus somnus [8,10,11]. As it has an excellent antibacterial activity against a number of bacteria affecting cattle including Pasteurella multocida, Pasteurella haemolytica, and Haemophilus somnus), this could make the drug an ideal candidate for treatment of primary bacterial pathogens involved in bovine shipping fever [12-14].

While work undertaken in healthy animals can give a guide to the distribution of an antibiotic in the body, most calves receiving florfenicol will be clinically ill with pneumonia $[9,15]$. The role of alveolar macrophages in the clearance of bacteria from lungs has attracted an interest [16]. Some of the antibiotics are accumulated in bronchial secretions and leukocytes and in turn, their penetration into the sub cellular compartments (lysosomes) would increase their clinical efficacies $[7,16]$. To guide effective therapy of pneumonia, this study was undertaken to investigate the disposition, distribution and the penetration pattern of florfenicol into respiratory tract secretions of clinically healthy and experimentally $P$. multocida-infected calves following i.v. and i.m administration at a dose rate of $20 \mathrm{mg} / \mathrm{kg}$ bwt.

\section{Material and Methods}

\section{Drug}

Florfenicol (Nuflor) was supplied by Schering-Plough Animal Health, La Grindoliere, France.

\section{Animals and husbandry}

Ten calves aged one-and-a-half month and weighing from 65 to $75 \mathrm{~kg}$ were used in the experimental work. The calves were housed individually in adjacent boxes that had a floor area of $4 \mathrm{~m}^{2}$ and a volume of $6 \mathrm{~m}^{3}$. The animals were bedded on straw. During acclimatization for one week and the subsequent treatment periods, calves were fed on milk replacer (free of antimicrobial substances, twice daily at 09.00 and 18.00) and alfalfa with drinking water available ad libitum. The animals were shaved over jugular vein to facilitate the collection of blood samples.

*Corresponding author: A. M. Abd El-Aty, Department of Pharmacology, Faculty of Veterinary Medicine, Cairo University, Giza-12211, Egypt, E-mail: abdelaty44@ hotmail.com

Received December 02, 2010; Accepted December 14, 2010; Published February 26, 2011

Citation: Ramadan A, Abd El-Aty AM (2011) Pharmacokinetics and Distribution of Florfenicol in Bronchial Secretions of Healthy and Pasteurella multocida Infected Calves. Pharm Anal Acta 2:117. doi:10.4172/2153-2435.1000117

Copyright: (c) 2011 Ramadan A, et al. This is an open-access article distributed under the terms of the Creative Commons Attribution License, which permits unrestricted use, distribution, and reproduction in any medium, provided the original author and source are credited. 
Citation: Anis SM, Hosny MM, Abdellatef HE, El-Balkiny MN (2011) Kinetic Spectrophotometric Determination of Betahistine Dihydrochloride and Etilefrine Hydrochloride in Pharmaceutical Formulation. Pharm Anal Acta 2:116. doi:10.4172/2153-2435.1000116

Page 2 of 6

\section{Drug administration}

The calves were allocated randomly to two groups, 5 calves each. Florfenicol was administered to each calf of the first group by intravenous (i.v.) route into the left jugular vein at a dose rate of 20 $\mathrm{mg} / \mathrm{kg} \mathrm{b}$ wt. The calves of the second group were given a single dose of florfenicol, $20 \mathrm{mg} / \mathrm{kg}$ b wt, intramuscularly (i.m.) into the right cervical musculature (the manufacturer's recommended site of injection to avoid irritation). After injection, the site was massaged vigorously to enhance distribution of the drug solution into the surrounding musculature [9].

\section{Experimental infection}

Two weeks later after the i.v. and i.m. administration of florfenicol, the calves were subjected to physical stress of a two-hour journey before they were inoculated. On day 0 at 22.00 (approximately six hours after journey), all calves were inoculated intratracheally with $P$. multocida. A first-pass culture of $P$. multocida was inoculated into $10 \mathrm{~mL}$ quantities of brain-heart-infusion broth (Oxoid), enriched with 5\% fetal calf serum, and incubated at $37^{\circ} \mathrm{C}$ in a shaking water bath for six hours [7]. Afterwards, the approximate bacterial count of each broth was 5 $\times 10^{9} \mathrm{cfu} / \mathrm{mL}$. A polyethylene catheter (Intramedic, VEL) was inserted through the right nostril and advanced into trachea until it was $5 \mathrm{~cm}$ proximal to the bifurcation. The inoculums consisted of $5 \mathrm{~mL}$ of the sixhour culture of $P$. multocida diluted with $5 \mathrm{~mL}$ of sterile $0.9 \%$ sodium chloride.

\section{Treatment schedule}

The first and second group was treated with florfenicol $(20 \mathrm{mg} / \mathrm{kg} /$ bwt) as aforementioned above. Treatment was initiated when the calves had a body temperature of more than $39.5^{\circ} \mathrm{C}$ and a respiratory rate of more than $52 / \mathrm{min}$.

\section{Clinical examination}

The calves were examined twice a day for 10 days ( 5 days before and 5 days after infection) at 09.00 and 18.00 . Body temperature and respiratory rate were recorded daily at 10.00 .

\section{Blood samples}

Blood samples were obtained from the catheterized right jugular vein before and after infection. Samples were collected immediately before and at $0.25,0.5,1,2,4,6,8,24,36$, and $48 \mathrm{~h}$ following i.v. and i.m. injections. Samples were centrifuged at $3000 \mathrm{rpm}$ for $15 \mathrm{~min}$ and sera were used for estimation of florfenicol concentration. The serum samples were stored at $-80^{\circ} \mathrm{C}$ pending analysis and the assay was performed within a week of obtainment.

\section{Cytological analysis}

Another blood samples were collected in vacutainer tubes (Venoject, Terumo) containing EDTA as an anti-clotting agent, once a day on the day of the inoculation (day 0 ) and on the following five days at 10.00 after drug administration. Total white cell counts and granulocyte/ agranulocyte ratios were determined by standard methods.

\section{Bronchial secretions}

Bronchoalveolar fluid samples were obtained from calves on day $0,3,4$, and 5 after florfenicol administration to infected animals. A polyethylene tube (Intramedic, VEL) with an external diameter of 4.8 $\mathrm{mm}$ was inserted through the right nostril and advanced into trachea and the bronchial tree until an elastic resistance felt. Fifty $\mathrm{mL}$ of a sterile $0.9 \%$ solution of sodium chloride at $37^{\circ} \mathrm{C}$ was injected and aspirated immediately by genital suction; approximately $75 \%$ of the infused fluid could be retrieved [7]. The neutrophil/macrophage ratio was determined in the bronchoalveolar fluid. Cytological specimens were prepared by cytocentrifugation (Cytocentrifuge, Shandon Scientific) and standard Wright Giemsa stains were used.

From each bronchoalveolar fluid sample $10 \mathrm{~mL}$ was stored in sterile plastic tubes at $4^{\circ} \mathrm{C}$ and examined for the presence of bacteria and Mycoplasmas within two hours after collection. All the samples were inoculated on three media: Colombia blood agar (Oxoid), PPLO agar (Difco) enriched with 25\% inactivated horse serum, 7\% yeast extract, $400 \mu \mathrm{g} / \mathrm{ml}$ ampicillin, $0.05 \%$ thallium acetate, and $1 \%$ glucose and Tween 80 PPLO agar (the same enriched and selective medium with 0.1 per cent Tween 80) [7]. The blood plates were evaluated after 24 or $48 \mathrm{~h}$ of incubation at $37^{\circ} \mathrm{C}$ in a carbon dioxide-enriched atmosphere. Mycoplasma plates were evaluated after two days and, if negative, daily until 14 days after inoculation. The bacteria were identified by the techniques described earlier [17].

\section{Analytical method}

The free florfenicol concentrations in serum and bronchial secretions were measured by a microbiological assay technique [18] using Bacillus subtilis (ATCC 6633) as the test organism [19]. Standard curves of florfenicol were prepared in pooled antibacterial free serum and bronchial secretions. Serum and bronchial secretions were directly added to the culture plates. The mean correlation coefficient $\left(r^{2}\right)$ of the standard curves was found to be 0.998 and the lower limit of quantification both in serum and bronchial fluid was $0.01 \mu \mathrm{g} / \mathrm{ml}$.

\section{Pharmacokinetic analysis}

The concentrations of florfenicol in serum and bronchial fluid were subjected to kinetic analysis, and the pharmacokinetic parameters were calculated by equations $[20,21]$. The non-compartmental parameters, including volume of distribution at steady state $\left(\mathrm{V}_{\mathrm{d}(\mathrm{ss})}\right)$, body clearance $\left(\mathrm{Cl}_{(\mathrm{B})}\right)$, and the mean residence time (MRT) were calculated according to the statistical moment theory [21]. The area under the blood concentration $\left(\mathrm{C}_{\mathrm{pt}}\right)$ time $(\mathrm{t})$ curve to infinity (AUC), and the area under the first moment curve $\left(\mathrm{AUMC}=\mathrm{C}_{\mathrm{pt}} \times \mathrm{t}^{2}\right)$ were calculated from the first to the last blood and bronchial sample using the trapezoidal rule, and an estimate of the residual area under the curve was obtained from $\mathrm{C}_{\mathrm{p}\left(\mathrm{t}^{*}\right)} / \beta$, where $\mathrm{C}_{\mathrm{p}\left(\mathrm{t}^{*}\right)}$ is the last measured blood and bronchial secretions concentration of florfenicol, and $\beta$ the overall elimination rate constant. An estimate of the residual part of the AUMC curve was obtained from $\mathrm{C}_{\mathrm{p}\left(\mathrm{t}^{*}\right)} \times \mathrm{t}^{*} / \beta$. The mean residence time (MRT) was calculated from AUC and AUMC (MRT = AUMC / AUC) [9].

\section{Statistical analysis}

Data obtained were analyzed by the analysis of variance, and the mean values were compared by students " $t$ " test. LSD was calculated by the SAS statistical analysis program [22]. The results are given as mean \pm SD.

\section{Results}

\section{Pharmacokinetic studies}

The mean concentrations of florfenicol in serum and bronchial secretions following i.v. and i.m injection in healthy and P. multocidainfected calves are shown in (Figure 1 and 2) respectively.

Values for the kinetic parameters describing the disposition of the drug are given in (Table 1). Following i.v. administration, the drug concentration decreased in a biexponential manner that could be described into a two-compartment open model. Florfenicol was slowly 
Citation: Anis SM, Hosny MM, Abdellatef HE, El-Balkiny MN (2011) Kinetic Spectrophotometric Determination of Betahistine Dihydrochloride and Etilefrine Hydrochloride in Pharmaceutical Formulation. Pharm Anal Acta 2:116. doi:10.4172/2153-2435.1000116

Page 3 of 6

distributed and eliminated with mean half-lives of ( 1.09 and $1.25 \mathrm{~h})$ and ( 4.10 and $4.84 \mathrm{~h}$ ) for the distribution and elimination phases in healthy and infected calves, respectively. The volume of distribution was less than $1 \mathrm{~L} / \mathrm{kg}$, indicating lower penetration into tissues. The total body clearance and the MRT were 0.15 and $0.11 \mathrm{~L} / \mathrm{kg} / \mathrm{h}$ and 0.05 and $0.04 \mathrm{~h}$, respectively.

The mean peak concentration of florfenicol in serum $\left(\mathrm{C}_{\max }, 3.70\right.$ and $4.06 \mu \mathrm{g} / \mathrm{mL})$ and bronchial secretions $(6.88$ and $7.62 \mu \mathrm{g} / \mathrm{mL})$ was reached $(3.07$ and $3.01 \mathrm{~h})$ and $(1.54$ and $1.70 \mathrm{~h})$ following i.m. injection in healthy and infected calves, respectively. P. multocida infection was significantly increased the mean peak concentration of florfenicol in bronchial secretions compared with pre-infection. (Table 2, Figure 2), complied that the drug was absorbed slowly from the site of injection, as indicated by its long absorption half-lives $\left(\mathrm{t}_{1 / 2 \mathrm{ab}}, 4.44\right.$ and $4.11 \mathrm{~h}$ ), respectively. The mean elimination half-life $\left(\mathrm{t}_{1 / 2 \mathrm{el}}\right)$ was 12.43 and 13.74 $\mathrm{h}$, indicating that the drug was slowly eliminated.

\section{Clinical findings}

During the five days before the infection and on the day of inoculation (day 0 ), none of the calves had suffered from fever and their

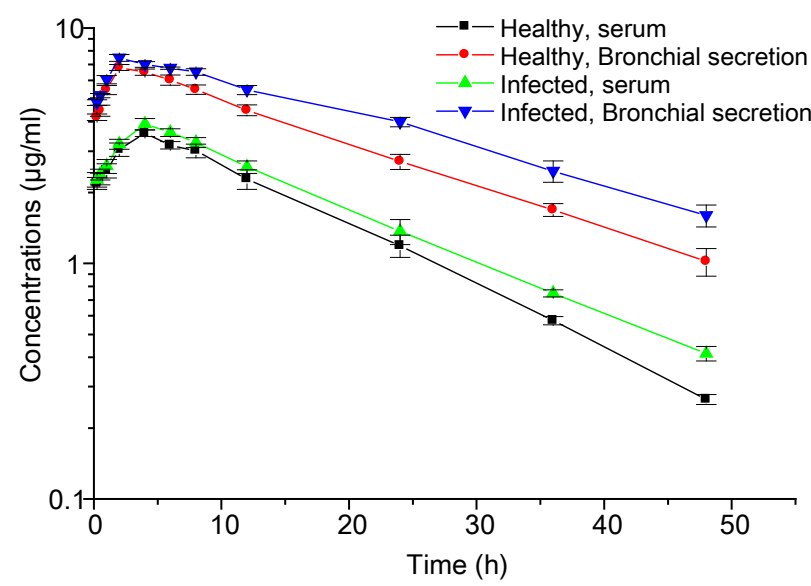

Figure 1: Semilogarithmic plot of the mean serum, and bronchial secretion concentrations $(\mu \mathrm{g} / \mathrm{ml})$ of florfenicol following intravenous injection of $20 \mathrm{mg} /$ $\mathrm{kg}$ b.wt in healthy and $P$. multocida infected calves.

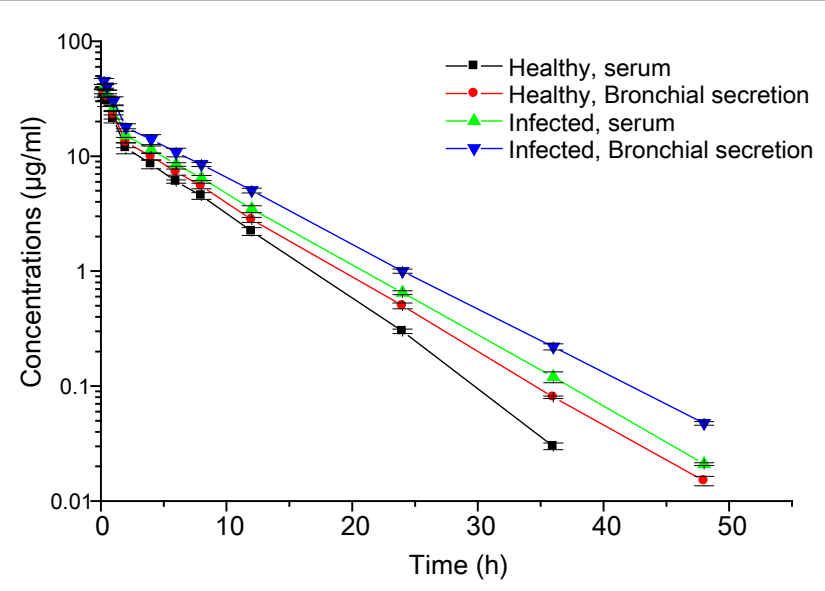

Figure 2: Semilogarithmic plot of the mean serum, and bronchial secretion concentrations $(\mu \mathrm{g} / \mathrm{ml})$ of florfenicol following intramuscular injection of $20 \mathrm{mg} /$ $\mathrm{kg}$ b.wt in healthy and $P$. multocida infected calves. respiratory rates were fluctuated between 25 and $31 / \mathrm{min}$. On the first day ( $12 \mathrm{~h}$ after the intratracheal challenge) the body temperatures as well as the respiratory rates were significantly higher than before infection (Table 3). The body temperatures of calves treated intramuscularly remained significantly higher than before infection on day 1, 2, 3 and 4 . However, on day 5 their body temperatures were significantly lower than the other days. On the contrary, the respiratory rates returned to the pre-inoculation values on day 4 and 5 .

\section{Hematological analysis}

The means and ranges of the total WBC counts recorded in the two groups of calves on the day of the intratracheal challenge and on the five days after inoculation are shown in (Table 4). The total WBC counts of all the calves were significantly higher on the first day after inoculation than before the intratracheal challenge. The counts returned to the pre-inoculation values on day 2 after infection in calves treated intramuscularly and on day 3 in intravenous -injected calves.

The means and ranges of granulocyte/agranulocyte (G/AG) ratio recorded in calves of both groups on the day of intratracheal challenge onwards had demonstrated severe granulocytosis on the first day after infection, compared with the pre-inoculation data (Table 4).

\section{Bronchoalveolar lavage (BAL)}

The mean neutrophil/macrophage $(\mathrm{N} / \mathrm{M})$ ratio in the BAL fluid is shown in (Table 4). There were significant increases in the N/M ratios on day 4 and 5 after infection, in calves treated intramuscularly.

P. multocida was not isolated from the BAL fluid samples taken from any day of the animals before the intratracheal challenge. Furthermore, no other respiratory pathogens were isolated from any calves before infection. Mycoplasma bovis was isolated from two of the five intravenous-treated calves on day 5 after inoculation. On all occasions the strains of $P$. multocida isolated was the same as that inoculated.

\section{Discussion}

This study used the bioassay to determine the pharmacokinetics and bronchial secretion concentrations of florfenicol in healthy and infected calves. The bioassay did not distinguish the active metabolite from the parent compound. Since the metabolites are microbiologically active, their presence may not necessarily interfere with determination of a therapeutic dosage regimen [23]. Lavy et al. [24] found that chemical (HPLC) and microbiological assay methods for florfenicol gave very similar test results.

The intrinsic antibacterial activity of the drug together with its pharmacokinetic properties after subcutaneous injection suggest that systemic florfenicol bronchopneumonia calves therapy should be explored, in field efficacy trials, as a means of eliminating P. haemolytica lung infections.

The results of this study had shown that the serum and bronchial secretions concentrations of florfenicol in experimentally $P$. haemolytica-infected calves remained above the minimum inhibitory concentrations (MICs) for the most sensitive bacteria ( $P$. multocida and $P$. haemolytica $(0.25$ to $1 \mu \mathrm{g} / \mathrm{mL})$, and A. pleuropneumoniae $(0.2$ to $1.56 \mu \mathrm{g} / \mathrm{mL}$ ) isolated from cattle [13,25] for 24 and $36 \mathrm{~h}$ post i.v. and i.m. injection. Similar results have been reported by Adams et al. [26], Lobell et al. [9], and Varma et al. [15], who found that free florfenicol concentrations in the serum of calves were remained above the MIC of the drug for one to two days.

The disposition kinetic of florfenicol in calves after a single i.v. injection was adequately described by a biexponential terms with a slow 
Citation: Anis SM, Hosny MM, Abdellatef HE, El-Balkiny MN (2011) Kinetic Spectrophotometric Determination of Betahistine Dihydrochloride and Etilefrine Hydrochloride in Pharmaceutical Formulation. Pharm Anal Acta 2:116. doi:10.4172/2153-2435.1000116

Page 4 of 6

distribution and elimination phases. Our findings were similar to those reported in calves [12,26] and cattle [15,27].

The apparent volume of distribution at steady-state (Vdss) is an indication of its diffusion into body tissues [28]. Florfenicol showed a low volume of distribution $(0.68 \mathrm{~L} / \mathrm{kg})$, indicating a lower penetration extent into tissues [20]. Our results showed that the volume of distribution is lower and the clearance rate is slower in bronchial secretions of infected calves compared to healthy ones. These findings were consistent with the higher serum and bronchial secretions concentrations recorded in infected calves compared to healthy ones. Similar results were observed by Thompson et al. [16] who found a high serum and lung concentrations of tilmicosin in acute pneumonic cattle than in healthy animals. On the other hand, florfenicol showed high body clearance rate $(0.15 \mathrm{~L} / \mathrm{kg} / \mathrm{h})$ in calves, the finding which is at variance to those reported by Afifi and Abo El-Sooud [19] in chicken. This could be attributed to the anatomical and physiological variations between different species.

After i.m. injection, the mean apparent elimination half-lives of

\begin{tabular}{|c|c|c|c|c|c|}
\hline \multirow{2}{*}{ Parameter } & \multicolumn{2}{|c|}{ Healthy } & \multicolumn{2}{|c|}{ Infected } & \multirow{2}{*}{$\begin{array}{c}\text { LSD } \\
(\operatorname{Pr}>F)\end{array}$} \\
\hline & S & BS & $\mathrm{S}$ & BS & \\
\hline $\mathrm{C}^{\circ}(\mathrm{g} / \mathrm{ml})$ & $42.35(4.20)^{\mathrm{b}}$ & $41.65(2.12)^{b}$ & $45.05(3.88)^{b}$ & $51.60(2.95)^{\mathrm{a}}$ & $4.536(0.001)$ \\
\hline A $(\mu \mathrm{g} / \mathrm{ml})$ & $26.22(2.60)^{\mathrm{ab}}$ & $24.70(1.60)^{\mathrm{b}}$ & $25.40(2.27)^{\mathrm{ab}}$ & $27.70(1.35)^{a}$ & $2.705(0.148)$ \\
\hline$\alpha\left(h^{-1}\right)$ & $0.639(0.04)^{a}$ & $0.591(0.05)^{\mathrm{ab}}$ & $0.560(0.06)^{\mathrm{bc}}$ & $0.512(0.02)^{c}$ & $0.061(0.003)$ \\
\hline$t_{1 / 2(\alpha)}(h)$ & $1.089(0.08)^{c}$ & $1.178(0.09)^{\mathrm{bc}}$ & $1.248(0.13)^{\mathrm{ab}}$ & $1.354(0.05)^{\mathrm{a}}$ & $0.125(0.002)$ \\
\hline$B(\mu \mathrm{g} / \mathrm{ml})$ & $16.13(1.69)^{c}$ & $16.95(1.93)^{c}$ & $19.65(1.75)^{b}$ & $23.27(1.99)^{\mathrm{a}}$ & $2.469(0.0001)$ \\
\hline$\beta\left(h^{-1}\right)$ & $0.169(0.004)^{a}$ & $0.149(0.004)^{b}$ & $0.144(0.008)^{b}$ & $0.127(0.003)^{c}$ & $0.007(0.0001)$ \\
\hline$t_{1 / 2(\beta)}(h)$ & $4.099(0.10)^{c}$ & $4.669(0.12)^{b}$ & $4.841(0.25)^{b}$ & $5.460(0.12)^{\mathrm{a}}$ & $0.215(0.0001)$ \\
\hline $\mathrm{V}_{\mathrm{c}}(\mathrm{L} / \mathrm{kg})$ & $0.467(0.05)^{a}$ & $0.481(0.02)^{a}$ & $0.447(0.04)^{a}$ & $0.389(0.02)^{b}$ & $0.045(0.002)$ \\
\hline $\mathrm{V}_{\mathrm{d}(\text { area })}(\mathrm{L} / \mathrm{kg})$ & $0.875(0.11)^{a}$ & $0.870(0.10)^{a}$ & $0.769(0.09)^{\mathrm{ab}}$ & $0.658(0.06)^{b}$ & $0.124(0.005)$ \\
\hline $\mathrm{V}_{\mathrm{d}(\mathrm{ss})}(\mathrm{L} / \mathrm{kg})$ & $0.681(0.09)^{\mathrm{a}}$ & $0.694(0.07)^{\mathrm{a}}$ & $0.628(0.09)^{\mathrm{ab}}$ & $0.545(0.05)^{b}$ & $0.101(0.026)$ \\
\hline $\mathrm{Cl}_{(\mathrm{B})}(\mathrm{L} / \mathrm{kg} / \mathrm{h})$ & $0.148(0.02)^{a}$ & $0.129(0.01)^{b}$ & $0.110(0.008)^{c}$ & $0.083(0.006) d$ & $0.014(0.0001)$ \\
\hline $\mathrm{AUC}\left(\mu \mathrm{g} / \mathrm{ml} . \mathrm{h}^{-1}\right)$ & $0.137(0.01)^{c}$ & $0.156(0.01)^{c}$ & $0.183(0.01)^{b}$ & $0.241(0.02)^{\mathrm{a}}$ & $0.020(0.0001)$ \\
\hline AUMC $\left(\mu \mathrm{g} / \mathrm{ml} \mathrm{h}^{-2}\right)$ & $6 . .337(0.29)^{c}$ & $4.838(0.40)^{d}$ & $7.026(0.22)^{\mathrm{b}}$ & $17.913(0.38)^{a}$ & $0.443(0.0001)$ \\
\hline MRT (h) & $0.047(0.003)^{b}$ & $0.031(0.001)^{d}$ & $0.039(0.004)^{c}$ & $0.075(0.004)^{a}$ & $0.004(0.0001)$ \\
\hline
\end{tabular}

$(a, b, c, d)$ Means with the same letter in the same row are not significantly different.

LSD = Least significant difference.

Table 1: Mean (SD) pharmacokinetic parameters of florfenicol in serum (S) and bronchial secretions (BS) after intravenous injection of 20 mg/kg b wt in healthy and Pasteurella multocida-infected calves $(n=5)$.

\begin{tabular}{|c|c|c|c|c|c|}
\hline \multirow{2}{*}{ Parameter } & \multicolumn{2}{|c|}{ Healthy } & \multicolumn{2}{|c|}{ Infected } & \multirow[t]{2}{*}{ LSD } \\
\hline & $S$ & BS & $S$ & BS & \\
\hline$t_{1 / 2(a b)}(h)$ & $4.44(0.09)^{\mathrm{a}}$ & $2.37(0.20)^{\mathrm{b}}$ & $4.11(0.50)^{\mathrm{a}}$ & $2.58(0.09)^{b}$ & 0.372 \\
\hline $\mathrm{C}_{\max }(\mu \mathrm{g} / \mathrm{mL})$ & $3.70(0.08)^{d}$ & $6.88(0.23)^{b}$ & $4.06(0.24)^{c}$ & $7.62(0.26)^{\mathrm{a}}$ & 0.289 \\
\hline$t_{\max }(h)$ & $3.07(0.21)^{a}$ & $1.54(0.10)^{b}$ & $3.01(0.14)^{a}$ & $1.70(0.08)^{\mathrm{b}}$ & 0.190 \\
\hline$t_{1 / 2(e))}(h)$ & $12.43(0.90)^{d}$ & $17.23(1.25)^{b}$ & $13.74(0.50)^{c}$ & $22.46(0.96)^{\mathrm{a}}$ & 1.262 \\
\hline AUC $\left(\mu \mathrm{g} / \mathrm{ml} \cdot \mathrm{h}^{-1}\right)$ & $0.096(0.009)^{c}$ & $0.195(0.02)^{b}$ & $0.108(0.007)^{\mathrm{c}}$ & $0.263(0.03)^{a}$ & 0.025 \\
\hline $\mathrm{AUC}_{\mathrm{BS}} / \mathrm{AUC}_{\mathrm{S}}$ & - & $2.529(0.04)^{a}$ & - & $2.034(0.10)^{a}$ & 0.111 \\
\hline$F\left(A \cup C_{i, m} / A \cup C_{i, v}\right)$ & $0.704(0.01)^{c}$ & $1.253(0.02)^{a}$ & $0.591(0.04)^{d}$ & $1.132(0.008)^{b}$ & 0.030 \\
\hline
\end{tabular}

$(a, b, c, d)$ Means with the same letter in the same row are not significantly different at

$(\mathrm{Pr}>\mathrm{F}$ 0.0001). LSD = Least significant difference.

Table 2: Mean (SD) pharmacokinetic parameters of florfenicol in serum (S) and bronchial secretions (BS) after a single intramuscular injection 20 mg/kg b wt in healthy and Pasteurella multocida-infected calves $(n=5)$.

\begin{tabular}{|c|c|c|c|}
\hline Time (days) & Measurement & Intravenous & Intramuscular \\
\hline 0 & $\begin{array}{l}\text { TEMP } \\
\text { RESP }\end{array}$ & $\begin{array}{c}38.20(0.16)(38.0-38.4)^{\mathrm{d}} \\
31.40(3.36)(27-35)^{\mathrm{e}}\end{array}$ & $\begin{array}{c}38.20(0.10)(38.1-38.3)^{\mathrm{e}} \\
31.60(2.70)(28-35)^{\mathrm{d}}\end{array}$ \\
\hline 1 & $\begin{array}{l}\text { TEMP } \\
\text { RESP }\end{array}$ & $\begin{array}{l}40.80(1.30)(39.0-42.0)^{\mathrm{a}} \\
85.80(3.49)(81.0-90.0)^{\mathrm{a}}\end{array}$ & $\begin{array}{l}40.0 .8(0.19)(39.8-40.3)^{\mathrm{a}} \\
83.00(2.24)(80.0-86.0)^{\mathrm{a}}\end{array}$ \\
\hline 2 & $\begin{array}{l}\text { TEMP } \\
\text { RESP }\end{array}$ & $\begin{array}{l}40.00(1.22)(39.8-40.1)^{\mathrm{b}} \\
66.00(4.12)(61.0-71.0)^{\mathrm{b}}\end{array}$ & $\begin{array}{l}39.10(0.16)(38.9-39.3)^{\mathrm{b}} \\
51.80(2.59)(48.0-55.0)^{\mathrm{b}}\end{array}$ \\
\hline 3 & $\begin{array}{l}\text { TEMP } \\
\text { RESP }\end{array}$ & $\begin{array}{l}39.02(0.24)(38.7-39.3)^{c} \\
53.80(2.86)(50.0-57.0)^{c}\end{array}$ & $\begin{array}{l}38.78(0.19)(38.5-39.0)^{c} \\
41.20(2.39)(38.0-44.0)^{c}\end{array}$ \\
\hline 4 & $\begin{array}{l}\text { TEMP } \\
\text { RESP }\end{array}$ & $\begin{array}{l}38.70(0.16)(38.5-38.8)^{c)} \\
42.80(2.39)(40.0-46.0)^{d}\end{array}$ & $\begin{array}{l}38.56(0.11)(38.4-38.7)^{d} \\
34.00(2.55)(31.0-37.0)^{d}\end{array}$ \\
\hline 5 & $\begin{array}{l}\text { TEMP } \\
\text { RESP }\end{array}$ & $\begin{array}{l}38.50(0.26)(38.2-38.8)^{\mathrm{cd}} \\
32.80(2.49)(29.0-35.0)^{\mathrm{e}}\end{array}$ & $\begin{array}{l}38.32(0.13)(38.2-38.5)^{\mathrm{e}} \\
32.00(1.58)(30.0-34.0)^{d}\end{array}$ \\
\hline LSD & $\begin{array}{l}\text { TEMP } \\
\text { RESP }\end{array}$ & $\begin{array}{l}0.732 \\
4.148\end{array}$ & $\begin{array}{l}0.119 \\
3.094\end{array}$ \\
\hline
\end{tabular}

$(a, b, c, d, e)$ Means with the same letter in the same column measurement are not significantly different at $(\operatorname{Pr}>\mathrm{F} 0.0001)$. LSD $=$ Least significant difference.

Table 3: Mean (SD) and ranges of body temperature (TEMP, $\left.{ }^{\circ} \mathrm{C}\right)$ and respiratory rates (RESP, $\min ^{-1}$ ) in groups of 5 calves infected experimentally with Pasteurella multocida and treated with florfenicol either intravenously or intramuscularly. 
Citation: Anis SM, Hosny MM, Abdellatef HE, El-Balkiny MN (2011) Kinetic Spectrophotometric Determination of Betahistine Dihydrochloride and Etilefrine Hydrochloride in Pharmaceutical Formulation. Pharm Anal Acta 2:116. doi:10.4172/2153-2435.1000116

Page 5 of 6

\begin{tabular}{|c|c|c|c|}
\hline Time (days) & Measurement & Intravenous & Intramuscular \\
\hline 0 & $\begin{array}{c}\text { WBC } \\
\text { G/AG } \\
\text { N/M }\end{array}$ & $\begin{array}{c}14.30(2.41)(10.0-16.0)^{c} \\
0.81(0.21)(0.55-1.10)^{c} \\
0.14(0.03)(0.11-0.17)^{c}\end{array}$ & $\begin{array}{l}13.30(2.59)(9.0-15.5)^{b} \\
0.81(0.25)(0.50-1.10)^{c} \\
0.14(0.02)(0.12-0.17)^{c}\end{array}$ \\
\hline 1 & $\begin{array}{l}\text { WBC } \\
\text { G/AG } \\
\text { N/M }\end{array}$ & $\begin{array}{c}30.00(5.70)(23.0-37.0)^{\mathrm{a}} \\
3.18(0.46)(2.60-3.80)^{\mathrm{a}} \\
\text { NS }\end{array}$ & $\begin{array}{c}27.60(4.93)(21.0-34.0)^{\mathrm{a}} \\
2.90(0.60)(2.10-3.70)^{\mathrm{a}} \\
\text { NS }\end{array}$ \\
\hline 2 & $\begin{array}{l}\text { WBC } \\
\text { G/AG } \\
\text { N/M }\end{array}$ & $\begin{array}{c}19.8(3.83)(15.0-24.0)^{\mathrm{b}} \\
1.98(0.30)(1.60-2.40)^{\mathrm{b}} \\
\text { NS }\end{array}$ & $\begin{array}{c}15.40(2.41)(12.0-18.0)^{\mathrm{b}} \\
1.48(0.30)(1.10-1.90)^{\mathrm{b}} \\
\text { NS }\end{array}$ \\
\hline 3 & $\begin{array}{l}\text { WBC } \\
\text { G/AG } \\
\text { N/M }\end{array}$ & $\begin{array}{c}16.40(2.41)(13.0-19.0)^{\mathrm{bc}} \\
2.12(0.49)(1.50-2.70)^{\mathrm{b}} \\
0.23(0.05)(0.17-0.29)^{\mathrm{b}}\end{array}$ & $\begin{array}{c}14.80(2.59)(11.0-18.0)^{b} \\
0.86(0.31)(0.50-1.20)^{c} \\
0.20(0.04)(0.15-0.26)^{b c}\end{array}$ \\
\hline 4 & $\begin{array}{l}\text { WBC } \\
\text { G/AG } \\
\text { N/M }\end{array}$ & $\begin{array}{c}16.00(2.74)(12.0-19.0)^{\mathrm{bc}} \\
0.86(0.04)(0.80-0.91)^{\mathrm{c}} \\
0.30(0.07)(0.21-0.39)^{\mathrm{ab}}\end{array}$ & $\begin{array}{c}13.80(2.86)(10.0-17.0)^{\mathrm{b}} \\
0.78(0.28)(0.45-1.10)^{\mathrm{c}} \\
0.25(0.02)(0.19-0.32)^{\mathrm{ab}}\end{array}$ \\
\hline 5 & $\begin{array}{l}\text { WBC } \\
\text { G/AG } \\
\text { N/M }\end{array}$ & $\begin{array}{c}14.60(1.14)(13.0-16.0)^{c} \\
0.80(0.16)(0.60-1.00)^{c} \\
0.36(0.05)(0.29-0.43)^{a}\end{array}$ & $\begin{array}{c}12.80(2.39)(10.0-16.0)^{\mathrm{b}} \\
0.80(0.20)(0.55-1.00)^{\mathrm{c}} \\
0.29(0.06)(0.21-0.37)^{\mathrm{a}}\end{array}$ \\
\hline LSD & $\begin{array}{l}\text { WBC } \\
\text { G/AG } \\
\text { N/M }\end{array}$ & $\begin{array}{l}4.381 \\
0.418 \\
0.069\end{array}$ & $\begin{array}{l}4.037 \\
0.455 \\
0.062\end{array}$ \\
\hline
\end{tabular}

a, b, c) Means with the same letter in the same column measurement are not significantly different at (Pr>F 0.0001). NS = Not sampled. LSD = Least significant difference.

Table 4: Mean (SD) and ranges of total blood cell counts (WBC, $\times 10^{3} \mathrm{~mm}^{3-1}$ ), blood granulocyte/agranulocyte ratios (G/AG) and BAL fluid neutrophil/macrophage ratios (N/M) in groups of 5 calves infected experimentally with Pasteurella multocida and treated with florfenicol either intravenously or intramuscularly.

florfenicol in serum and bronchial secretions were (12.43 and 17.23

h) and (13.74 and 22.46) in healthy and infected calves, respectively. Similar half-life values (18 and $5.57 \mathrm{~h}$ ) were previously reported in serum of healthy calves $[9,26]$. This is strongly supports the idea that florfenicol partitions into lung secretions and possibly other tissues and becomes sequestered.

The bioavailability of florfenicol following i.m. injection was moderate with approximately 70.4 and 59.1 being absorbed in healthy and infected calves, respectively. These values were similar to those reported in calves (78.5 and $88.8 \%[9,26])$ and in equine (81\%, [29])).

The results described in this article were similar to an earlier observation, which indicated that $P$. multocida could be able to produce severe acute pneumonia in conventional calves [6]. The development of clinical signs (pyrexia, tachyponea, anorexia), hematological changes (leucocytosis, neutophilia) and bacteriological findings were very similar to those reported in clinical cases of "shipping fever" $[5,30]$. The principle method for treating pneumonic pasteurellosis is antibiotic therapy [31]. Florfenicol has been suggested as an appropriate antimicrobial drug for the treatment of respiratory disease in cattle $[15,27]$, the suggestion which is supported by the results of the present study.

During the clinical efficacy experiments, no calves died in the treated groups. Body temperature, respiratory rate, hematological and bronchoalveolar-lavage fluid parameters returned to normal significantly faster in i.m. treated group than the i.v. Similar findings were reported by Lockwood et al. [14] and Navetat et al. [32] who concluded that treatment with single dose of florfenicol is effective in most cases of cattle or pigs bacterial pneumonia.

\section{Conclusion}

These results suggest that i.m. injection of florfenicol could be used for treatment of acute $P$. multocida bronchopneumonia in calves.

\section{References}

1. Vermeersch $H$, Vandenbossche G, Remon JP, Vandendriessche K, Sustronck B, Muylle E, Deprez P (1994) Pharmacokinetics and efficacy of nebulized sodium ceftiofur in the treatment of Pasteurella haemolytica bronchopneumonia. Proceedings of the European Association of Veterinary Pharmacology and Toxicology, $6^{\text {th }}$ International Congress, Edinburgh, pp 94-95.
2. Scott PR (1995) Efficacy of strategic tilmicosin injection during an outbreak of respiratory disease in housed beef calves. Br Vet J 151: 587-589.

3. Dyer RM (1982) The bovine respiratory disease complex: a complex interaction of host, environment and infectious factors. Compendium on Continuing Education for the Practicing Veterinarian 4: S296-S304.

4. Confer AW, Panciera RJ, Corstvet RE, Rummage JA, Fulton RW (1984) Bovine pneumonic pasteurellosis: effect of culture age of Pasteurella haemolytica used as a live vaccine. Am J Vet Res 45: 2543-2545.

5. Gibbs HA, Allan EM, Wiseman A, Selman IE (1984) Experimental production of bovine pneumonic pasteurellosis. Res Vet Sci 37: 154-166.

6. Ames TR, Markham RJ, Opuda-Asibo J, Leininger JR, Maheswaran SK (1985) Pulmonary response to intratracheal challenge with Pasteurella haemolytica and Pasteurella multocida. Can J of Comp Med 49: 395-400.

7. Sustronck B, Deprez p, Muylle E, Vermeersch H, Vandenbossche G, et al (1995) Evaluation of the nebulisation of sodium ceftiofur in the treatment of experimental Pasteurella haemolytica bronchopneumonia in calves. Res Vet Sci 59: 267-271.

8. Varma, KJ, Adams PE, Lobell RD, Lamendola JF, Houdeshell JW, et al. (1986) Pharmacokinetics of florfenicol in veal calves $\mathrm{J}$ Vet Pharmacol Ther 9: 412-425

9. Lobell RD, Varma, KJ, Johnson JC, Sams RA, Gerken DF, et al (1994) Pharmacokinetics of florfenicol following intravenous and intramuscular doses to cattle. J Vet Pharmacol Ther 17: 253-258.

10. Neu HC, Fu KP (1980) In vitro activity of chloramphenicol and thiamphenicol analog. Antimicrob Agents Chemother 18: 311-316.

11. Syriopoulou VP, Harding AL, Goldmann DA, Smith AL (1981) In vitro antibacterial activity of fluorinated analogs of chloramphenicol and thiamphenicol. Antimicrob Agents and Chemother 19: 294-297.

12. Varma KJ, Adams PE, Powers TE, Powers JD, Lamendola JF (1986) Pharmacokinetics of florfenicol in veal calves. J Vet Pharmacol Ther 9: 412425

13. Hörmansdorfer S, Bauer J (1996) Resistance pattern of bovine Pasteurella. Berl Munch Tierarztl Wochenschr 109: 168-171.

14. Lockwood P, De Haas VD, Katz TMS, Varma KJ (1996) Clinical efficacy of florfenicol in the treatment of shipping fever in cattle in the USA. Medicina Veterinaria 13: 34-38.

15. Varma KJ, Walker RD, Sams RA, Holland RE, Trenti F (1994) Pharmacokinetics and distribution of florfenicol in bronchial secretions and tissue cage fluid in cattle. Proceedings $18^{\text {th }}$ World Buiatrics Congress: $26^{\text {th }}$ Congress of the Italian Association Buiatrics, Bologna, Italy, pp. 547-550.

16. Thompson TD, Lawrence K (1994) Micotil: pharmacokinetics of tilmicosin, 
Citation: Anis SM, Hosny MM, Abdellatef HE, El-Balkiny MN (2011) Kinetic Spectrophotometric Determination of Betahistine Dihydrochloride and Etilefrine Hydrochloride in Pharmaceutical Formulation. Pharm Anal Acta 2:116. doi:10.4172/2153-2435.1000116

semi-synthetic macrolide antibiotic, in cattle. Proceedings of the European Association for Veterinary Pharmacology and Toxicology, $6^{\text {th }}$ International Congress, Edinburgh, 7-11 August 1994. pp 55-56.

17. Carter GR (1984) "Diagnostic Procedure in Veterinary Bacteriology and Mycology", $4^{\text {th }}$ edn., Springfield, Illinois, Charles C. Thomas, USA, pp. 129-142.

18. Bennett JV, Brodie JL, Benner EJ, Kirby WM (1966) Simplified, accurate method for antibiotic assay of clinical specimens. Appl Microbiol 14: 170-177.

19. Afifi, NA, Abo El-Sooud KA (1997) Tissue concentrations and pharmacokinetics of florfenicol in broiler chickens. Br Poult Sci 38: 425-428.

20. Baggot J.D. (1978) Some aspects of clinical pharmacokinetics in veterinary medicine. Journal of Veterinary Pharmacology and Therapeutics 1: 5-18.

21. Gibaldi M (1984) Biopharmaceutics and clinical pharmacokinetics, $3^{\text {rd }}$ edn., Philadelphia, Lea and Febiger. pp 45-111.

22. SAS Institute (1982) SAS User's Guide. SAS Institute, Cary, NC. pp 191-193.

23. Sams RA (1994) Florfenicol: Chemistry and metabolism of a novel broadspectrum antibiotic. International Symposium on bovine Respiratory Disease. New Therapeutic Advances 13-17.

24. Lavy E, Ziv G, Soback S, Gilckman A, Winkler M (1991) Clinical pharmacology of florfenicol in lactating goats. Proceedings of the European Association for Veterinary Pharmacology and Toxicology, $5^{\text {th }}$ International Congress, Copenhagen, Denmark, 1991. Act Vet Scandinavica Suppl. 87: 133-136.
25. Ueda Y, Suenaga I (1995) In vitro antibacterial activity of florfenicol against Actinobacillus pleuropneumoniae. J Vet Med Sci 57: 363-364.

26. Adams PE, Varma KJ, Powers TE, Lamendola JF (1987) Tissue concentrations and pharmacokinetics of florfenicol in male veal calves given repeated doses. American Journal of Veterinary Research 48: 1725-1732.

27. Soback S, Paape MJ, Filep R, Varma, KJ (1995) Florfenicol pharmacokinetics in lactating cows after intravenous, intramuscular and intramammary administration. J Vet Pharmacol Ther 18: 413-417

28. Gilman AG, Goodman LS, Gilm`an A (1980) Goodman and Gilman's: The Pharmacological Basis of Therapeutics, $6^{\text {th }}$ edn., Macmillan, New York, P 21

29. McKellar QA, Varma KJ (1996) Pharmacokinetics and tolerance of florfenicol in Equidae. Equine Veterinary Journal 28: 209-213.

30. Allan EM, Gibbs HA, Wiseman A, Selman IE (1983) Pasteurella haemolytica pneumonia in weaned housed single suckled calves. Vet Rec 112: 327

31. Whiteley LO, Maheswaran SK, Weiss DJ, Ames TR, Kannan MS (1992) Pasteurella haemolytica $\mathrm{A} 1$ and bovine respiratory disease: pathogenesis. J Vet Intern Med 6: 11-22.

32. Navetat H, Concordet D, Lockwood P, Madelenat A, Espinasse (1995) Efficacy of florfenicol in the therapy of acute pneumonia in housed beef calves. Revue de Medecine Veterinaire 148: 567-574. 